\title{
LEGAL IMPLICATIONS OF ACCESSION TO THE EUROPEAN UNION ON GEOGRAPHICAL INDICATIONS AND DESIGNATIONS OF ORIGIN FOR AGRICULTURAL PRODUCTS AND FOODSTUFFS
}

\begin{abstract}
Andreas Auer*
Summary: Accession to the European Union (EU) implies the acceptance of the rights and obligations attached to the EU system and its institutional framework, known as the "acquis communautaire". Each new Member State of the EU will have to apply this as it stands at the time of accession. The subject matter of this Article is the part of the "acquis" dealing with the protection of geographical indications and designations of origin for agricultural products and foodstuffs. The author first describes the pre-accession situation, then points out the possibilities of transitional arrangements, and later goes into the details of Regulation 510/2006 - the most important legal source for the protection of geographical indications and designations of origin after accession to the EU. Where appropriate, the relevant ECJ cases are cited. Some of these cases are described in detail. Finally, to give an overview of the existing means of legal protection, the author contemplates the international dimension by examining WTO law.
\end{abstract}

\section{Introduction}

In the EU, many Member States have well-known regions from which special foodstuffs originate. Examples include in Italy Prosciutto di San Daniele, in France Camembert de Normandie, in Austria Tiroler Speck, in Germany Nürnberger Lebkuchen and in the Czech Republic Budějovické pivo. Looking at Croatia, Paški sir, Dalmatinski pršut or Slavonski domaći kulen would be such regional specialties. When joining the EU, the question arises whether the new Member State may protect its specialities' designations against the usage of these designations by producers from another Member State. Assuming Croatia becomes a Member State of the $\mathrm{EU},{ }^{1}$ would it then be possible for Slovenian companies, for instance, to produce ham in their country and sell it there as Dalmatinski pršut? The following contribution considers the situation in this field of law, and in so doing seeks to answer this question.

\footnotetext{
* Dr. Andreas Auer is a research assistant at the Institute for European Law and Institute for Public International Law and International Relations, Johannes Kepler University, Linz. This article was completed in May 2006.

${ }^{1}$ Accession negotiations started on 3 October 2005.
} 
The importance of this question is based on the fact that consumers nowadays are tending to attach greater importance to the quality of foodstuffs rather than to quantity; this tendency corresponds to the growing demand of consumers for agricultural products or foodstuffs with an identifiable geographical origin. ${ }^{2}$ This is one reason why there is a need to protect the geographical names of high quality products. Another reason is that designations of origin and geographical indications are important marketing tools for farmers, both in developed and developing countries, who focus on quality production and who want to "market" their regional specialties. Designations of origin and geographical indications are denominations that indicate the geographical origin of a food product or a handicraft. They are signs used on goods that have a specific geographical origin and indicate qualities or a reputation that derive from that place of origin. Geographical indications are distinct from indications of source, which are nothing more than signs that specify that a product originates from a specific geographical region (examples include "Made in France", "Product of the USA", "Swiss made", etc), without bearing a "quality" function.

The improvement of both intra-community and international protection for designations of origin and geographical indications has always been a prevailing objective of the EU agricultural quality policy, which aims at promoting the production of quality products and supporting rural development. ${ }^{3}$

Within the EU, designations of origin and geographical indications for agricultural products and foodstuffs are protected by Council Regulation (EC) No 510/2006 (hereinafter Regulation 510/2006). ${ }^{4}$ The Regulation was adopted by the Council on 20 March 2006 and applies from 31 March 2006. ${ }^{5}$ It replaces Council Regulation 2081/92, ${ }^{6}$ a necessary measure to bring the EU system for the protection of geographical indications into conformity with WTO law. ${ }^{7}$

\footnotetext{
${ }^{2}$ See preamble of Council Regulation (EC) 510/2006 of 20 March 2006 on the protection of geographical indications and designations of origin for agricultural products and foodstuffs [2006] OJ L 93/12.

${ }^{3}$ See preamble of Regulation 510/2006, at para 2.

${ }^{4}$ See $\mathrm{n} 2$.

${ }^{5}$ See art 20 of Regulation 510/2006.

${ }^{6}$ Council Regulation (EEC) 2081/92 of 14 July 1992 on the protection of geographical indications and designations of origin for agricultural products and foodstuffs [1992] OJ L208/1 (for the last available consolidated version see: http://eur-lex.europa.eu/LexUriServ/site/en/consleg/1992/R/01992R2081-20040501-en.pdf). Art 19 of Regulation 510/2006: 'Regulation (EEC) No 2081/92 is hereby repealed. References made to the repealed Regulation shall be construed as being made to this Regulation and should be read in accordance with the correlation table in Annex III'. Transitional provisions are to be found in art 17 of Regulation 510/2006.

${ }^{7}$ For more on the inconsistency of Regulation 2081/92 with WTO law, see infra VII.
} 
At the international level, the first and at the same time the most important international multilateral text dealing with geographical indications as such is the Agreement on Trade-Related Aspects of Intellectual Property Rights (TRIPS) of $1994 .{ }^{8}$ The TRIPS Agreement is one of the multilateral agreements of the World Trade Organization (WTO), which all states must ratify when joining the WTO ("single undertaking approach"). This has implications for states aiming to become a member of the EU without being a member of the WTO at the same time, since the $\mathrm{EU}^{10}$ is a member of the WTO. International agreements concluded by the EU are binding on all Member States pursuant to art 300 (7) EC. Accordingly, the WTO agreements form part of the acquis communautaire and hence are binding also for EU Member States not yet members of the WTO. At the moment, all Member States of the EU are members of the WTO. The same applies to the current candidate countries for EU accession, ie Croatia, Turkey and the Former Yugoslav Republic of Macedonia. Other potential candidate countries in the future, such as the Republic of Serbia and Montenegro or Bosnia and Herzegovina, are not yet WTO members.

\section{Pre-accession protection of geographical indications and designations of origin}

One of the first legal steps for a European country on its way to accession to the EU is the concluding of an Association Agreement, nowadays called a "Stabilisation and Association Agreement" (SAA). Such kinds of agreements are concluded once the Copenhagen criteria for EU accession have been fulfilled. They provide, inter alia, for cooperation in the fields of

\footnotetext{
${ }^{8}$ The TRIPS Agreement is available at: http://www.wto.org/english/docs_e/legal_e/legal_ e.htm. It was signed - as part of the Final Act of Embodying the Results of the Uruguay Round of Multilateral Trade Negotiations - on 15 April 1994 and entered into force on 1 January 1995. For a legislative comment, see Daniel J. Gervais, 'The TRIPS Agreement: Interpretation and Implementation' (3/1999) 21 European Intellectual Property Review (EIPR) 156. There are various other international agreements (eg the Paris Convention for the Protection of Industrial Property (1883), the Madrid Agreement for the Repression of False or Deceptive Indications of Source (1891), the Lisbon Agreement for the Protection of Appellations of Origin and their International Registration (1958) or the Convention Establishing the World Intellectual Property Organisation (1967)) which grant some kind of protection for geographical indications as an intellectual property right (see $\mathrm{n}$ 101). Because of its availability and the number of signatory members, the TRIPS Agreement is currently the principal international instrument for protecting and defending geographical indications.

${ }^{9}$ For this notion, see the introduction to the WTO Agreements at the homepage of the WTO: http://www.wto.org/english/docs_e/legal_e/ursum_e.htm (Agreement Establishing the World Trade Organization: "The WTO framework ensures a "single undertaking approach" to the results of the Uruguay Round - thus, membership in the WTO entails accepting all the results of the Round without exception').

${ }^{10}$ To be more precise, it must be noted that it is not the EU but the European Communities (EC) that are a member of the WTO. Due to its lack of legal personality, the EU cannot become a member of an international organisation.
} 
political dialogue, regional cooperation, approximation of national legislation with Community law, and the establishment of a free trade area.

Croatia, a current country candidate for EU accession, ${ }^{11}$ signed an SAA in October 2001, which entered into force on 1 February $2005 .{ }^{12}$ Art 71 in connexion with Annex VIII of the SAA deals with the issue of intellectual property. Pursuant to that provision, "the Parties confirm the importance that they attach to ensure adequate and effective protection and enforcement of intellectual...property rights". Para 2 obliges Croatia to "take the necessary measures in order to guarantee no later than three years after the entry into force of this Agreement a level of protection of intellectual, industrial and commercial property rights similar to that existing in the Community, including effective means of enforcing such rights". Finally, a Joint Declaration - attached to the SAA - concerning art 71 expressly states that, for the purpose of the SAA, intellectual property includes in particular copyright, patents, trademarks and geographical indications, including appellation of origins, as well as protection against unfair competition. Additional protection of geographical indications, although only for wines, is provided by the "Agreement between the European Community and the Republic of Croatia on the reciprocal recognition, protection and control of wine names". ${ }^{13}$ Pursuant to art 4 para 4 "[t]he protection provided for in this Agreement shall prohibit in particular any use of protected names for wines which do not originate in the geographical area indicated or in the place where the expression is traditionally used". Art 12 and art 17 provide for a procedure in the event of an infringement of the Agreement by private persons or by a party.

The Former Yugoslav Republic of Macedonia - another candidate country $^{14}$ - signed an SAA in April 2001, which entered into force on 1 April 2004. Turkey - a candidate country as well ${ }^{15}$ - had already signed in September 1963 an "Agreement establishing an Association" (Ankara Agreement) and in November 1970 an Additional Protocol, entering into force on January $1973 .{ }^{16}$ The acceding countries of Romania and Bulgaria $^{17}$ concluded with the EC a "Europe Agreement establishing an

\footnotetext{
${ }_{11}$ Accession negotiations with Croatia were opened on 3 October 2005.

12 The Stabilisation and Association Agreement between the European Communities and their Member States, of the one part, and the Republic of Croatia, of the other part (2005) OJ L26/3.

13 (2001) OJ L342/50.

14 The European Council decided on 16 December 2005 to grant candidate country status to the Former Yugoslav Republic of Macedonia.

15 The EU opened accession negotiations with Turkey on 3 October 2005.

${ }_{16}$ Agreement establishing an Association between the European Economic Community and Turkey (1973) OJ C113/1.

${ }^{17}$ Both countries signed the Treaty of Accession on 25 April 2005 (see (2005) OJ L157/11) and are supposed to become members of the EU on 1 January 2007 (see Notice concerning the entry into force of the Treaty of Accession (2005) OJ L157/10).
} 
association". ${ }^{18}$ All these agreements contain provisions corresponding to those of the SAA with Croatia. ${ }^{19}$

Additional, but rather weak protection is afforded by the TRIPS Agreement. For more details on this, see infra VI. Besides protection by way of these international agreements, producers in candidate countries may seek protection for their product names in accordance with art 5 of Regulation 510/2006. ${ }^{20}$

At national level, candidate countries of course may protect their geographical indications and designations of origin by national law. ${ }^{21}$ But once the country becomes a member of the EU, it must cease this protection in respect of geographical indications and designations of origin registered under Regulation 510/2006, ${ }^{22}$ unless transitional periods are granted.

\section{Transitional Arrangements}

Shortly after accession to the EU, the European Commission may adopt transitional arrangements by a Commission Regulation to ensure continuing protection of the relevant geographical indications and designations of origin. It did so, for example, in the latest "accession round". Art 1 of Commission Regulation 918/2004 ${ }^{23}$ reads as follows: "The national protection of geographical indications and designations of origin within the meaning of Regulation (EEC) No. 2081/92 existing in the Czech Republic, Estonia, Cyprus, Latvia, Lithuania, Hungary, Malta, Poland, Slovenia and Slovakia on 30 April 2004 may be upheld by those Member States until 31 October 2004. Where an application for registration under Regulation

${ }_{18}$ The Europe Agreement establishing an association between the European Communities and their Member States, of the one part, and Romania, of the other part (1994) OJ L357/2; and the Europe Agreement establishing an association between the European Communities and their Member States, of the one part, and the Republic of Bulgaria, of the other part (1994) OJ L358/3.

${ }^{19}$ Regarding the Agreement with the Former Yugoslav Republic of Macedonia, see articles 68, 71, Annex VII and the Joint Declaration concerning article 71; regarding Romania, see articles 67, 70, Annex XIX and the Joint Declaration concerning article 67; and regarding Bulgaria, see articles 67, 70, 114 and the Joint Declaration 16.

${ }^{20}$ For more on this, see infra IV.3.a.

${ }^{21}$ With regard to the protection of Croatian geographical indications by Croatian law, see Pravilnik o oznakama izvornosti i oznakama zemijopisnog podrijetla hrane, Narodne novine 80/2005 (Croatian Gazette), available at: http://www.nn.hr/.

${ }^{22}$ For more on the relation between national law and Community law protecting geographical indications and designations of origin, see infra V.2.

${ }^{23}$ Commission Regulation (EC) 918/2004 of 29 April 2004 introducing transitional arrangements for the protection of geographical indications and designations of origin for agricultural products and foodstuffs in connection with the accession of the Czech Republic, Estonia, Cyprus, Latvia, Lithuania, Hungary, Malta, Poland, Slovenia and Slovakia (2004) OJ L163/88. 
(EEC) No. 2081/92 is forwarded to the Commission by 31 October 2004, such protection may be upheld until a decision has been taken in accordance with article 6 of that Regulation. The consequences of such national protection in cases where the name is not registered at Community level are entirely the responsibility of the Member State concerned".

Another way to grant a new Member State a transitional period lies in the possibility to agree on this directly in the accession treaty.

\section{Post-accession protection of geographical indications and designations of origin - Council Regulation 510/2006}

On becoming a Member State of the EU, it is exclusively Regulation $510 / 2006$ that establishes the means of registration and protection of geographical indications and designations of origin at Community level. Exceptionally, it is possible to register geographical indications or designations of origin directly through the accession treaty without having recourse to Regulation 510/2006. ${ }^{24}$

Regulation 510/2006 provides a general framework, but the detailed rules on the actual features of a product are to be defined by the producers in the product specification. ${ }^{25}$ It simplifies the registration procedure compared to Regulation 2081/92 and clarifies the role of EU Member States in order to make the registration process more efficient. The centrepiece of new Regulation 510/2006 is the definition of a "single document" for applications containing all the necessary information for registration. ${ }^{26}$ Such a standardised form should result in greater transparency as well as equal treatment for all applicants.

\section{Scope and objectives}

Regulation 510/2006 forms part of the EU's Common Agricultural Policy. Correspondingly, the scope of Regulation 510/2006 27 is limited to certain agricultural products and foodstuffs, to be found in Annex I and Annex II to this Regulation (for example, beer, pasta, baker's wares, wool, cork) and Annex II to the EC Treaty (including, for example, meat, fruit, milk and honey used for human consumption) for which a link exists between the characteristics of the product or foodstuff and the geographical origin exists. ${ }^{28}$ On the other hand, Regulation 510/2006 does not apply

\footnotetext{
${ }^{24}$ See for instance with regard to Czech products $n 34$.

${ }^{25}$ See infra IV.3.a.

${ }^{26}$ See infra IV.3.a.

${ }^{27}$ Art 1 para 1 subpara 1.

${ }^{28}$ See preamble of Regulation 510/2006, at para 8. See also ECJ case C-312/98 Schutzverband gegen Unwesen in der Wirtschaft eV $v$ Warsteiner Brauerei Haus Cramer GmbH \& Co KG [2000] ECR I-9187 para 46.
} 
to industrial products. Neither does it apply to mineral water ${ }^{29}$ nor to wines (except wine vinegars ${ }^{30}$ ) and spirits, ${ }^{31}$ since these are governed by specific rules. ${ }^{32}$

The main objective of Regulation 510/2006 is the protection of names. This form of protection benefits farmers and (small-scale) producers whose products thereby obtain exclusiveness. Furthermore, the said Regulation aims to establish a means of providing information to consumers..$^{33}$ Consumers are to be protected against misleading information, and producers against unfair competition. ${ }^{34}$

\section{Protected designation of origin (PDO) and protected geographical indication (PGI)}

Art 2 para 1 of Regulation 510/2006 defines two different types of denominations regarding the product origin, namely geographical indica-

\footnotetext{
${ }^{29}$ Mineral and spring waters were excluded from the scope of Regulation 2081/92 (now Regulation 510/2006) by Council Regulation (EC) 692/2003 of 8 April 2003 amending Regulation (EEC) 2081/92 on the protection of geographical indications and designations of origin for agricultural products and foodstuffs (2003) OJ L99/1 (see preamble, at para 3 and art 1 para 16 thereof). Since then, these products are solely the subject of Council Directive $80 / 777$ /EEC of 15 July 1980 on the approximation of the laws of the Member States relating to the exploitation and marketing of natural mineral waters (1980) OJ L229/1 (as last amended by Regulation (EC) 1882/2003 of the European Parliament and of the Council of 29 September 2003 (2003) OJ L284/1; a consolidated version may be consulted at: http:// eur-lex.europa.eu/LexUriServ/site/en/ consleg/1980/L/01980L0777-20031120-en.pdf). Even if that Directive does not have exactly the same purpose as Regulation 510/2006, it does nevertheless provide adequate regulation at Community level.

${ }^{30}$ Wine vinegars were first included through art 1 (1) of Regulation 692/2003 (see n 29). Art 1 para 1 subpara 2 of Regulation 510/2006 assumes that provision.

${ }^{31}$ See art 1 para 1 subpara 2 of Regulation 510/2006.

${ }^{32}$ See Council Regulation (EEC) 1576/89 of 29 May 1989 laying down general rules on the definition, description and presentation of spirit drinks (1989) OJ L160/1; Council Regulation (EEC) 1601/91 of 10 June 1991 laying down general rules on the definition, description and presentation of aromatized wines, aromatized wine-based drinks and aromatized wine-product cocktails (1991) OJ L149/1; Council Regulation (EC) 1493/1999 of 17 May 1999 on the common organisation of the market in wine (1999) OJ L179/1 (for the implementing regulations of the European Commission, see: http://ec.europa.eu/comm/ agriculture/markets/wine/leg/index_en.htm). Apart from that, some Member States have introduced national systems which provide for quality assurance labels especially for wines. Examples are the French Appellation d'Origine Contrôlée (AOC) system, the Denominazione di Origine Controllata (DOC) system used in Italy, the Denominación de origen system used in Spain, or the Austrian Districtus Austriae Controllatus (DAC).

${ }^{33}$ See preamble, at paras 2, 4 and 6. See further the ECJ, for wine designations, in Case C306/93 SMW Winzersekt GmbH v Land Rheinland-Pfalz [1994] ECR I-5555 ("Champagne") para 25: '[T]he final consumer should receive sufficiently accurate information to enable him to form an opinion of the products in question'. The same must apply respectively to agricultural products and foodstuffs covered by Regulation 510/2006.

34 'A framework of Community rules on a system of protection ... ensures fair competition between the producers of products bearing such indications and enhances the credibility of the products in the consumer's eyes' (preamble of Regulation 510/2006, at para 6).
} 
tions and designations of origin. A "designation of origin" means that "the name of a region, a specific place or, in exceptional cases, a country", may be "used to describe an agricultural product or a foodstuff", subject to three cumulative conditions:

- the product must originate in that geographical area;

- the quality or characteristics of the product or foodstuff must be essentially or exclusively due to a particular geographical environment with its inherent natural and human factors;

- the production, processing and preparation of the product or foodstuff must take place in the defined geographical area.

The definition of a "geographical indication" differs from that of the "designation of origin" only as regards the second and third condition:

- the product or foodstuff must possess a specific quality, reputation or other characteristic attributable to that geographical origin;

- the production and/or processing and/or preparation of the product or foodstuff concerned must take place in the defined geographical area.

Hence, the distinction between the two categories depends on how closely the product is linked to the specific geographical area which gives its name. In the case of a geographical indication, the link can be more flexible, ie the link is necessary but does not need to be essential or exclusive as it is in the case of a designation of origin. Moreover, for a designation of origin, the full manufacture, ie production, processing and preparation of the product (or, in other words, all the stages from the production of the raw materials to the preparation of the final product ${ }^{35}$ ) must take place in the defined geographical area, whereas for a geographical indication only one phase (either production or processing or preparation) must take place there. To sum up, a PDO requires an objective and very close link between the features of the product and its geographical origin, while in regard to a PGI the link may consist simply in the reputation of the product, if it owes its reputation to its geographical origin. The idea is that a geographical indication deserves protection even when it cannot be proven that the product owes its special features to its region of origin.

\footnotetext{
${ }_{35}$ But see the exception with regard to raw materials in art 2 para 3 subpara 1 of Regulation 510/2006: "Notwithstanding paragraph 1 (a), certain geographical designations shall be treated as designations of origin where the raw materials of the products concerned come from a geographical area larger than, or different from, the processing area, provided that: (a) the production area of the raw materials is defined;

(b) special conditions for the production of the raw materials exist; and

(c) there are inspection arrangements to ensure that the conditions referred to in point (b) are adhered to".

These geographical designations must have been recognised as designations of origin in the country of origin before 1 May 2004 (art 2 para 3 subpara 2 of Regulation 510/2006). Examples include Prosciutto di Parma and Roquefort.
} 
Examples for PGIs are Bayrisches Bier, Budějovické pivo, Tiroler Speck, Scotch Lamb or Turrón de Alicante, whereas Roquefort, Feta, Parmigiano Reggiano, Prosciutto di Parma or Wachauer Marille are PDOs. Which category producers choose for registration depends on the characteristics of their products. Only when it is feasible for production, processing and preparation to be conducted in the geographical area in question can they apply for the registration of a designation of origin, otherwise they must settle for a geographical indication. The producers of Nürnberger Lebkuchen, for instance, need for production raw materials such as candied lemon peel, almonds and many spices which do not originate from Nuremberg. As a consequence, the producers were able to consider the registration of the name Nürnberger Lebkuchen only as a geographical indication but not as a designation of origin. Concerning the Croatian cheese Paški sir, it will depend on whether the producers settled on the Isle of Pag produce, process and prepare both the raw materials of the cheese and the final product in that area. Anyway, the differentiation is not really decisive, as the protection afforded is the same for both categories of protection.

Art 2 (2) of Regulation 510/2006 provides for exceptions to the condition that the name of a product should designate the defined area from which the product comes, so that a non-geographical product name, like, for example, the name "Feta", ${ }^{36}$ may be registered as a designation of origin or a geographical indication. In that case, all the other conditions referred to in art 2 (1) of Regulation 510/2006 must be fulfilled.

\section{Procedure}

To enjoy protection in every Member State of the EU, geographical indications and designations of origin must be registered at Community level. The registration procedure for new names originating in the EU involves two stages. The first is carried out at national level by the appropriate authorities of the Member State where the geographical area concerned is located; the second is conducted at Community level by the European Commission. The registration system is open, voluntary and free of charge. The register is kept by the Commission. So far, more than 700 geographical indications (for products other than wines and spirits $^{37}$ ) are registered under Regulation 510/2006. ${ }^{38}$ The procedure for

\footnotetext{
${ }^{36}$ For more on this product name, see infra V.1.

37 Concerning wines, the EU has registered some 4,200 geographical indications (see European Commission, 'Intellectual Property - Why do geographical indications matter to us?' <http://ec.europa.eu/comm/trade/issues/sectoral/intell_property/argu_en.htm>). As for the protection of geographical indications for wines and spirits, see $\mathrm{n} 32$.

38 See IP/06/339, 20 March 2006; IP/05/298, 15 March 2005 (both downloadable from: http://europa.eu/rapid/); and $\operatorname{COM(2005)~} 698$ final/2, p 2 (downloadable from: http:// eur-lex.europa.eu/en/prep/index.htm).
} 
registering a name is provided for in articles 5 to 7 of the respective Regulation. ${ }^{39}$

\section{a) Procedure at national level: Application for registration and objection}

Registration is the result of a private voluntary initiative of the producers of a certain product. In principle, only a group, ie an association of producers or processors working with the same agricultural product or foodstuff, whatever its legal form or composition, is entitled to file an application for registration. ${ }^{40}$ Such a group as a whole prepares the registration application. Other interested parties, eg consumers, may participate in the group. Exceptionally, a single producer may also apply for registration. The implementing rules of the European Commission set out the conditions under which a natural or legal person may be treated as a group and thus be entitled to file an application. ${ }^{41}$ Finally, in transborder cases, a joint application of several groups may be lodged. ${ }^{42}$

In the case of an application relating to the geographical area of a Member State, the application must be sent to the competent national authority of that Member State. ${ }^{43}$ Where, on the other hand, the application relates to a geographical area of a third country, including

39 Art 17 of Regulation 2081/92 provided for a "simplified procedure". This provision was repealed by art 1 (15) of Regulation 692/2003 (see n 29), but it continued to apply to names registered or names for which registration was sought under the procedure provided for by art 17 prior to the entry into force of Regulation 692/2003, that is, 24 April 2003. Art 17 (1) of Regulation 510/2006 now determines that names that, on the date of the entry into force of this Regulation, are listed in the Annex of Commission Regulation (EC) 1107/96 of 12 June 1996 on the registration of geographical indications and designations of origin under the procedure laid down in article 17 of Council Regulation [EEC] 2081/92 (1996) OJ L148/1 [as last amended by Regulation [EC] 704/2005 (2006) OJ L118/14]) shall be automatically entered in the register referred to in art 7 (6) of Regulation 510/2006.

${ }^{40}$ Art 5 para 1 subpara 1 of Regulation 510/2006. A group may lodge a registration application only for the agricultural product or foodstuffs which it produces or obtains (art 5 para 2). Any operator located in the area and marketing agricultural products or foodstuffs (ie farmers, producers, processors) who is not part of the original applicant group, but whose products conform to the corresponding registered specification, may use the registered designation of origin or geographical indication as well (see art 8 para 1 of Regulation 510/2006).

${ }^{41}$ Art 5 para 1 subpara 2. See accordingly Commission Regulation (EEC) 2037/93 of 27 July 1993 laying down detailed rules of application of Council Regulation (EEC) 2081/92 [now Regulation 510/2006] on the protection of geographical indications and designations of origin for agricultural products and foodstuffs (1993) OJ L185/5 (as last amended by Commission Regulation (EC) 2168/2004 of 17 December 2004 (2004) OJ L371/12; for a consolidated version, see: http://eur-lex.europa.eu/LexUriServ/site/en/consleg/ 1993/ R/01993R2037-20041219-en.pdf)

42 Art 5 para 1 subpara 3 of Regulation 510/2006.

${ }^{43}$ Art 5 (4) of Regulation 510/2006. A list of national authorities and control bodies may be consulted at: http://ec.europa.eu/comm/agriculture/foodqual/protec/national/index_ en.htm. 
candidate countries for EU accession, it must be sent to the European Commission, either directly or via the national authorities of the third country concerned. ${ }^{44}$ In both cases, the application must include the name and address of the applicant group and must be accompanied by a product specification whose contents are set out in art 4 of Regulation 510/2006. ${ }^{45}$ Accordingly, the specification has to include all the elements required to show that the applicant name fulfils the conditions set out in art 2 of Regulation 510/2006 with regard to the definition of a designation of origin or a geographical indication, ${ }^{46}$ including the name of the product, a description of both the product ${ }^{47}$ and the method of production, ${ }^{48}$ the definition of the geographical area,${ }^{49}$ evidence that the product concerned originates from that area, ${ }^{50}$ the elements proving a link with the geographical environment, ${ }^{51}$ and reference to the national compliance

${ }^{44}$ Art 5 para 9 subpara 2 of Regulation 510/2006. Non-binding guidance regarding the procedures applicable for groups and individuals outside the EU may be consulted at: http:// ec.europa.eu/comm/agriculture/foodqual/protec/thirdcountries/index_en.htm.

${ }^{45}$ Art 5 (3) and (9) of Regulation 510/2006.

${ }^{46}$ The specification is defined by the applicant group, ie the producers draw up their own rules, and the discipline required is self-imposed. Once formulated, the rules are binding and constitute the reference for national inspections. Only products that comply with the rules may be marketed under the PDO or PGI concerned.

${ }^{47}$ Including the raw materials and principal physical (shape, weight, etc), chemical (eg minimum fat content or maximum water content), microbiological (eg type of bacteria present) or organoleptic (colour, taste, smell, etc) characteristics of the product or the foodstuff. The product description allows for the objective differentiation of the product in question from other products of the same category. Thus, it is also a guideline for controls by national inspection services.

${ }^{48}$ That is, the method of obtaining the product, the authentic and unvarying local methods of production and - if desired - information concerning packaging (see $n$ 53). The production method must be explained in such a way that any producer within the area can produce the product concerned on the basis of the information given in the specification. Otherwise, full effectiveness of art 8 (1) of Regulation 510/2006 would be impaired.

49 That is, the area where the production and/or processing takes place. Natural and/or human factors limit the geographical area. See, for example, joined cases C-465/02 \& C466/02 Germany and Denmark v Commission (ECJ 25 October 2005) ("Feta II") (not yet published in the ECR), para 22: "[T]he geographical area inherent in a designation may not cover an entire country. In the case of the name "Feta", it has therefore been noted that the defined geographical area (...) covers only the territory of mainland Greece and the department of Lesbos; all other islands and archipelagos are excluded because the necessary natural and/or human factors do not apply there").

50 This relates to the traceability of a product: the path from the area of production to the final destination of the product must be specified.

${ }^{51}$ This element of the specification is the most important concerning the registration. The requirements for the link differ with regard to designations of origin and geographical indications (see supra IV.2). But in both cases the explanation of the link should focus on the effect of the geographical environmental or other local conditions (eg human factors like local know-how or special production skills in the case of PDOs) on the specific quality of the product. As regards PGIs, a consumer survey, for instance, can be useful to demonstrate the specific reputation of the product in the geographical area concerned. 
authorities or bodies. ${ }^{52}$ The specification is the main evidence in support of the application. ${ }^{53}$ Therefore, the specification should provide detailed information. Furthermore, the application must include a "single document", setting out the main points of the specification and a description of the link between the product and the geographical area concerned..$^{54}$ If the geographical area concerned is situated in a third country, the application additionally has to prove that the name in question is protected in its country of origin. ${ }^{55}$ This requirement is in compliance with art 24 (9) of the TRIPS Agreement. ${ }^{56}$ Besides these compulsory documents, applicants

${ }^{52}$ The requirements for such mandatory national authorities or (official/private) inspection bodies of Member States or third countries and the subject of control are laid down in articles 10 and 11 of Regulation 510/2006. For each registered PDO or PGI, it must be specified which control body is appointed. The costs of these control bodies must be covered by the producers using the protected name (see art 18 of Regulation 510/2006). A list with all relevant national authorities and/or control bodies is downloadable from: http://ec.europa. eu/comm/agriculture/foodqual/protec/national/index_en.htm.

${ }^{53}$ Moreover, the content of the specification is of major importance to producers as it establishes the conditions to be observed subsequently. In this way, it defines the scope of the protection of a PDO or PGI. See, for example, case C-108/01 Consorzio del Prosciutto di Parma and Salumificio S. Rita SpA v Asda Stores Ltd. et al [2003] ECR I-5121. In the "Parma case", a British company was selling in the UK, among other things, ham bearing the description "Parma ham", purchased pre-sliced from another British company, which itself purchased the ham boned but not sliced from an Italian producer, who was a member of the Consorzio del Prosciutto di Parma. Therefore, the Consorzio del Prosciutto di Parma brought proceedings against both British companies requiring them to cease their activities, on the ground that these activities were contrary to the rules applicable to Parma ham laid down in the specification. According to the specification, the Parma ham had to be sliced and packed in Parma, otherwise it could not be purchased as "Parma ham". The ECJ ruled that "Regulation No 2081/92 [now Regulation 510/2006] must be interpreted as not precluding the use of a PDO from being subject to the condition that operations such as the slicing and packaging of the product take place in the region of production, where such a condition is laid down in the specification" (para 50). The Court agreed with the plaintiffs that the slicing and packaging of the ham constitute important operations which may harm the quality and hence the reputation of the PDO if they are carried out in conditions that result in a product not possessing the organoleptic qualities expected (para 68). A corresponding decision was taken by the ECJ in the "Grana Padano case" (case C-469/00 Ravil SARL v Bellon import SARL et al [2003] ECR I-5053), where the specification of "Grana Padano" cheese required the grating and packaging operations to be carried out in the region of production. In both cases, the ECJ qualified the requirements imposed by the specification as measures having equivalent effect to a quantitative restriction on exports within the meaning of art $29 \mathrm{EC}$, but which were justified under art $30 \mathrm{EC}$ on grounds of the protection of industrial and commercial property. For a comment on both cases, see Bernard O'Connor, 'Overview of the EC Case Law Protecting Geographical Indications: The Slicing of Parma Ham and the Grating of Grana Padano Cheese' (7/2004) 26 EIPR, p 313. In reaction to these cases, the latest version of Regulation 2081/92 and now art 4 (2) (e) of Regulation 510/2006 explicitly grant the possibility to add information concerning packaging if the applicant so determines and gives reasons why the packaging must take place in the defined geographical area to safeguard quality or ensure the origin or ensure control.

${ }_{54}$ Art 5 (3) (c) of Regulation 510/2006.

55 Art 5 (9) of Regulation 510/2006.

56 "There shall be no obligation under this Agreement to protect geographical indications which are not or cease to be protected in their country of origin, or which have fallen into 
may add voluntarily any other supporting documents, as for example results of surveys proving the reputation of a name. Also photographs, recipes or the like can be helpful.

Where the registration application concerns a geographical area in a Member State, the appropriate national authority of that Member State must review whether the application is justified and meets the conditions of Regulation 510/2006. ${ }^{57}$ This review includes a national objection procedure. For that purpose, the Member State has to ensure adequate publicity of the application (including all elements laid down in art 5 [3] of Regulation 510/2006) and must provide a reasonable period within which an objection - based on a violation of Regulation 510/2006 - may be lodged. ${ }^{58}$ The Member State may take a favourable decision if all requirements of Regulation 510/2006 are met, otherwise it shall decide to reject the application. A favourable decision and the product specification ${ }^{59}$ on which the decision is based have to be published in the Member State concerned. ${ }^{60}$ Moreover, a favourable decision must be contestable at national level and forwarded to the European Commission ${ }^{61}$

disuse in that country". For more on the TRIPS Agreement, see infra VI. The insertion of art 5 (9) in Regulation 510/2006 was necessary to implement the rulings and recommendations of the WTO Dispute Settlement Body (for more on this, see infra VII).

57 Art 5 para 4 subpara 2 of Regulation 510/2006.

58 Art 5 para 5 subpara 1 of Regulation 510/2006.

59 This requirement is to be seen as a reaction to criticism in the past on sometimes impeded access to the product specification. Criticism was expressed, for example, in the "Parma case" (see n 53), paras 82 et seq; and the "Gran Padano case" (see n 53), paras 91 et seq. In the aftermath of these two cases, the Commission adopted Commission Regulation (EC) 383/2004 of 1 March 2004 laying down detailed rules for applying Council Regulation (EEC) No 2081/92 as regards the summary of the main points of the product specifications (2004) OJ L64/16, to "ensure the transparency of the requirements in the specifications" (preamble, at para 4).

${ }^{60}$ Art 5 para 5 subpara 5 of Regulation 510/2006.

${ }^{61}$ All objections to an application for registration coming from the same Member State should be dealt with before submitting the application to the Commission, because these objections cannot be examined during the registration procedure at Community level (see case T-215/00 La Conqueste SCEA vs. Commission [2001] ECR II-181, paras 44 et seq: "[U]nder the scheme for registering objections established by Regulation 2081/92 [now Regulation 510/2006], the procedural safeguards afforded to individuals fall exclusively within the responsibility of the Member States and do not involve the exercise of any discretion by the Commission. Thus, article 7(1) of Regulation No 2081/92 [now Regulation 510/2006] grants only to the Member States the right to raise objections to registration before the Commission"; see furthermore case C-447/98 Molkerei Großbraunshain and Bene Nahrungsmittel GmbH v Commission [2000] ECR I-9097, para 75: "Such objections must in principle be dealt with before that Member State forwards to the Commission ... an application for registration"). Member States may maintain national protection of the names forwarded to the Commission until the date upon which a decision by the Commission on the registration is taken (see art 5 para 6 of Regulation 510/2006). 


\section{together with further documents ${ }^{62}$ specified in art 5 (7) of Regulation $510 / 2006 .{ }^{63}$}

\section{b) Procedure at Community level: Review by the European Commission}

The European Commission's task is then to examine the registration application, ${ }^{64}$ within a period of 12 months, to ensure that the application is justified and meets the conditions of Regulation 510/2006. ${ }^{65}$

For instance, it checks whether the applicant name is generic within the meaning of art 3 of Regulation 510/2006, because generic names

\footnotetext{
${ }^{62}$ All documents sent to the Commission must be in one of the official languages of the institutions of the EU or accompanied by a certified translation in one of those languages (art 5 para 10 of Regulation 510/2006).

${ }^{63}$ The Commission publishes each month a list of names for which registration applications have been submitted to it (art 6 para 1 subpara 2 of Regulation 510/2006). The list is available at: http://ec.europa.eu/comm/agriculture/foodqual/protec/applications/index_en.htm.

${ }^{64}$ In the past, the European Commission regularly called during the review for the independent advice of the "Committee" according to art 6 para 5 subpara 2 of Regulation 2081/92. With Commission Decision 93/53/EEC of 21 December 1992 setting up a scientific committee for designations of origin, geographical indications and certificates of specific character (1993) OJ L13/16), the European Commission set up a "Scientific Committee" for the purpose of examining, at the Commission's request, the technical problems relating to, inter alia, the application of Regulation 2081/92. According to art 3 of that Decision, the members of the Scientific Committee are appointed by the Commission from among highly-qualified experts with competence in the fields referred to in art 2 thereof. Under articles 7 (1) and 8 (1) thereof, the Committee is to meet at the request of a representative of the Commission, and its proceedings are to relate to matters on which the Commission has requested an opinion (eg on the generic character of a name). Regulation 510/2006 continues with this practice by declaring in art 15 (1): "The Commission shall be assisted by the Standing Committee on Protected Geographical Indications and Protected Designations of Origin”. Pursuant to art 15 (3) thereof, the Committee shall adopt its own Rules of Procedure.

${ }_{65}$ Art 6 para 1 subpara 1 of Regulation 510/2006. See case C-269/99 Carl Kühne GmbH \& Co KG and Others v Jütro Konservenfabrik GmbH \& Co KG [2001] ECR I-9517 ("Spreewälder Gurken"), paras 53, 54: "[T]he decision to register a designation as a PDO or as a PGI may only be taken by the Commission if the Member State concerned has submitted to it an application for that purpose and that such an application may only be made if the Member State has checked that it is justified. That system of division of powers is attributable particularly to the fact that registration assumes that it has been verified that a certain number of conditions have been met, which requires, to a great extent, detailed knowledge of matters particular to the Member State concerned, matters which the competent authorities of that State are best placed to check. Under that system of division of powers, it is for the Commission, before registering a designation in the category applied for, to verify, in particular, first, that the specification which accompanies the application complies with article 4 of Regulation No 2081/92 [now art 4 of Regulation 510/2006], that is to say that it contains the required information and that that information does not appear to contain obvious mistakes, and, secondly, on the basis of the information contained in the specification, that the designation satisfies the requirements of article 2 (2) (a) or (b) of Regulation No 2081/92 [now art 2 (1) (a) or (b) of Regulation 510/2006]".
} 
cannot be registered according to that provision. ${ }^{66}$ A name that has become generic means "the name of an agricultural product or a foodstuff which, although it relates to the place or the region where this product or foodstuff was originally produced or marketed, has become the common name of an agricultural product or a foodstuff in the Community". ${ }^{67}$ Examples of names which are considered to be generic include French fries or Emmenthal cheese. ${ }^{68}$

When examining a name wholly or partially homonymous with a name already registered under Regulation 510/2006, the Commission must pay due regard to local and traditional usage and the actual risk of confusion. ${ }^{69}$

Where the Commission reaches the conclusion that the application satisfies the conditions for registration laid down in Regulation 510/2006, it publishes the "single document" (see supra IV.3.a) in the Official Journal of the EU ("first publication")..$^{70}$ Within six months from the date of that publication, statements of objection can be transmitted to the Commission. ${ }^{71}$ If the Commission receives no statement of objection, it registers the applicant name ${ }^{72}$ and publishes the registration in

${ }^{66}$ The same applies to a name which conflicts with the name of a plant variety, an animal breed, a homonymous name or a trademark (art 3 para 2, 3 and 4 of Regulation 510/2006). It should be noted that a name that has been registered despite its generic or conflicting character is protected anyhow by Regulation 510/2006 as long as the registration has not been revoked.

${ }^{67}$ Art 3 para 1 subpara 1 of Regulation 510/2006. Thereby, account must be taken of all the factors, in particular (a) the existing situation in the Member State and in areas of consumption, and (b) the relevant national or Community laws (art 3 para 1 subpara 2). For a good explanation of what a generic name is, see R.W. Benson, 'Wine Briefs: The Generic Problem' (1976) 62 American Bar Association Journal 129: "When a product's geographical name becomes accepted as signifying the type of product, rather than its geographic source, the name is considered generic and it becomes part of public domain". In practice, difficulties have arisen again and again when determining whether a name has become generic or not (see infra V.). Nevertheless, it has not been possible so far to draw up at Community level a list of generic names of agricultural products or foodstuffs. To verify the eventually generic character of a name, it might in some cases be necessary for the Commission to send the Member States a questionnaire on the manufacture and consumption of a certain product and on how well known that name was amongst consumers in each of the States. It did this, for example, in the "Feta case" (see infra V.1.).

${ }^{68}$ See case C-448/98 Criminal proceedings against Jean-Pierre Guimont [2000] ECR I-10663 ("Emmenthal").

${ }^{69}$ For more details, see art 3 (3) of Regulation 510/2006.

70 Art 6 para 2 subpara 1 of Regulation 510/2006. An updated list of "first publications" may be consulted at http://ec.europa.eu/comm/agriculture/foodqual/protec/firstpub/index_en.htm. If the information sent to the Commission within the "single document" appears to be insufficient, the Commission may ask the Member State concerned to communicate any relevant complementary information, including a copy of the specification (see COM[2005] 698 final/2, para 8 of the explanatory memorandum).

${ }^{71}$ In detail, see infra IV.3.c.

${ }^{72}$ Registration is done by way of a Commission Regulation (see Commission Regulation 1107/96 [see n 39] and Commission Regulation [EC] 2400/96 of 17 December 1996 on the 
the Official Journal ("second publication"). ${ }^{73}$ The Commission keeps a current register of protected designations of origin and protected geographical indications. ${ }^{74}$ It should be mentioned here that, so far, no name of a third country has been registered, either under Regulation 2081/92 or under Regulation 510/2006.

If, on the other hand, the Commission considers, after examination, that the name does not satisfy the conditions of Regulation 510/2006, it rejects the application per decision, following the procedure referred to in art 15 (2) of Regulation 510/2006. ${ }^{75}$ Under that provision, the Commission is assisted by a Committee composed of representatives of the Member States and chaired by a representative of the European Commission. Art 15 (2) of Regulation 510/2006 refers to articles 5 and 7 of the Decision $1999 / 468 / \mathrm{EC},{ }^{76}$ which set up the procedure that the Commission has to follow. Accordingly, the Commission submits to the Committee a draft of the measures to be taken. The Committee delivers its opinion on this draft by the majority laid down in art 205 (2) EC. The Commission can adopt the measures envisaged if they correspond with the Committee's opinion. Where the measures envisaged are not in accordance with the opinion of the Committee, or in the absence of an opinion within the prescribed time limits, the Commission must submit its proposal to the Council of the EU which then acts by a qualified majority. If the Council has not taken a decision at the expiry of a period of three months from the date of referral, the proposed measures are adopted by the Commission, that is, the Commission may reject the application by a decision.

\section{c) Objection procedure at Community level}

As already mentioned above (IV.3.b), statements of objection can be transmitted to the Commission. ${ }^{77}$ The objection procedure ensures that

entry of certain names in the "Register of protected designation of origin and protected geographical indications" provided for in Council Regulation [EEC] 2081/92 on the protection of geographical indications and designations of origin for agricultural products and foodstuffs (1996) OJ L327/11 [as last amended by Commission Regulation [EC] 1623/2005 of 4 October 2005 supplementing the Annex to Regulation [EC] 2400/96 as regards the entry of certain names in the Register of protected designations of origin and protected geographical indications (2005) OJ L259/15]).

73 Art 7 (4) of Regulation 510/2006.

${ }^{74}$ A list of registered PDOs/PGIs may be consulted at: http://ec.europa.eu/comm/agriculture/qual/en/ 1bbaa_en.htm or http://ec.europa.eu/comm/agriculture/qual/en/1bbab_ en.htm.

${ }^{75}$ Art 6 para 2 subpara 2 of Regulation 510/2006.

${ }^{76}$ Council Decision 1999/468/EC of 28 June 1999 laying down the procedures for the exercise of implementing powers conferred on the Commission (1999) OJ L184/23.

77 All documents sent to the Commission during the objection procedure must be drafted in an official language of the EU institutions or accompanied by a certified translation into one of those languages (art 7 para 7 of Regulation 510/2006). 
denominations will not be unjustifiably protected. Any Member State ${ }^{78}$ or third country, thus including candidate countries, may object to the proposed registration by lodging a duly substantiated statement. ${ }^{79}$ The same applies to natural or legal person having a legitimate interest that is established or resident in a Member State other than the one applying for the registration, or in a third country. ${ }^{80}$

After receiving a statement of objection, the Commission first checks its admissibility. ${ }^{81}$ Where it is admissible,${ }^{82}$ the Commission invites the interested parties to engage in appropriate consultations. Responsibility is left to the Member States in order to improve the chances of acceptable decisions being reached. If an agreement is reached within six months without amending substantially ${ }^{83}$ the published "single document", the Commission, after being informed of the agreement, registers the applicant name and publishes the registration in the Official Journal. ${ }^{84}$ Otherwise, the Commission takes a decision in accordance with the procedure referred to in art 15 (2) of Regulation 510/2006 (see supra IV.3.b). This decision shall be published in the Official Journal. ${ }^{85}$

${ }^{78}$ But see the "Carl Kühne case" (see n 65), para 55:"[I]t follows from the wording and the scheme of article 7 of Regulation No 2081/92 [now Regulation 510/2006] that a statement of objection to a registration cannot come from the Member State which has applied for the registration and that the objection procedure established by article 7 of that regulation is not therefore intended to settle disputes between the competent authority of the Member State which has applied for registration of a designation and a natural or legal person resident or established in that Member State". This has been confirmed by the ECJ in the "Molkerei Großbraunshain case" (see n 61), para 74 of the order.

79 Art 7 (1) of Regulation 510/2006.

${ }^{80}$ Art 7 para 2 subpara 1 of Regulation 510/2006. In the case of natural or legal persons established or resident in a Member State, such a statement shall be lodged with that Member State (art 7 para 2 subpara 2). In the case of natural or legal persons established or resident in a third country, such a statement shall be lodged with the Commission, either directly or via the authorities of the third country concerned (art 7 para 2 subpara 3). Statements of objection generally come from manufactures that use the applicant designation.

${ }^{81}$ Art 7 para 3 subpara 2 of Regulation 510/2006. To be admissible, a statement of objection must be transmitted to the Commission within the time limit set out in art 7 (1) and has to show: that the conditions laid down in art 2 are not met, or that registration of the name would be contrary to art 3 (2), (3) and (4), or that it would jeopardise the existence of an identical name or trademark, or that the applicant name is to be considered generic (art 7 para 3 subpara 1$)$.

${ }^{82}$ Where a statement of objection has been declared admissible on the grounds that registration of the proposed name would jeopardise the existence of an entirely or partly identical name or the existence of products which have been legally on the market for at least five years preceding the date of the publication provided for in art 6 (2) of Regulation 510/2006, provision may be made for a transitional period up to 5 years under art 7 (5) thereof (art 13 para 3 subpara 1 thereof).

83 Otherwise the Commission has to repeat the review of the application.

${ }^{84}$ Art 7 para 5 subpara 1 and 2 of Regulation 510/2006.

${ }^{85}$ Art 7 para 5 subpara 3 and 4 of Regulation 510/2006. 
Besides the objection procedure set out in Regulation 510/2006, additional judicial relief is provided by art 230 EC. Accordingly, all acts of the European Commission or, as appropriate, of the Council of the EU in the application of Regulation 510/2006 are defeasible by action for annulment. An action may be brought by a Member State, the European Parliament, the Council, the Commission or by any natural or legal person to whom a decision has been addressed or who is directly and individually concerned by the decision in question, ${ }^{86}$ for example the applicant whose application has been denied, or an opponent whose objection has been rejected.

\section{d) Changes to specifications}

A group according to art 5 (1) and (2) of Regulation 510/2006 and having a legitimate interest may apply for the approval of an amendment to a specification. The procedure to be followed for such an application depends on whether the change involves one or more amendments to the "single document", or only minor amendments or no change to the "single document". Details are laid down in art 9 of Regulation 510/2006. The amended specification has to be published in the Official Journal.

\section{e) Cancellation of registration}

Art 12 of Regulation 510/2006 provides for two cases of possible cancellation of the registration of a PDO or PGI. First, the Commission may initiate - ex officio - the procedure referred to in art 15 (2) of Regulation $510 / 2006$ (see supra IV.3.b) for the cancellation if it takes the view that compliance with the conditions of the specification for a certain product is no longer ensured. ${ }^{87}$ Secondly, any natural or legal person having a legitimate interest may request the cancellation, giving reasons for the request. ${ }^{88}$

\section{Labelling (Logos)}

Agricultural products and foodstuffs originating in the EU marketed under a name registered in accordance with Regulation 510/2006 have to be labelled with either the indications "PDO/PGI" or the Community

\footnotetext{
${ }^{86}$ The European Court of Justice has jurisdiction in actions brought by a Member State, the European Parliament, the Council or the Commission. However, in the case of an action brought by a natural or legal person, it is not the ECJ but the Court of First Instance that has jurisdiction (art 225 para $1 \mathrm{EC}$ ).

87 The Commission will adopt detailed rules concerning the conditions for cancellation of registration (art 12 para 1 in connection with art 16 lit $\mathrm{k}$ of Regulation 510/2006).

${ }^{88}$ In that case, the procedure provided for in articles 5 to 7 of Regulation 510/2006 shall apply mutatis mutandis (art 12 para 2 subpara 2 thereof).
} 
symbols associated with them, ${ }^{89}$ whereas products originating in a third country may use these labels. ${ }^{90}$

The labelling of agricultural products and foodstuffs is subject to the general rules in Directive 2000/13/EC. ${ }^{91}$ Additional special provisions will probably be adopted. ${ }^{92}$ The mandatory labelling of products marketed under "PDO" or "PGI" helps to reinforce the credibility of the registration system. ${ }^{93}$

Finally, Regulation 2037/93 94 sets up the Community symbol indicating PDO and PGI products in order to add value and credibility to registered products and to provide information for consumers. ${ }^{95}$ Furthermore, the respective Regulation lays down the conditions which have to be met if the symbols are used. ${ }^{96}$

\section{Co-existence of a registered name and an unregistered name}

The European Commission may decide to allow, under the procedure provided for in art 15 (2) of Regulation 510/2006 (see supra IV.3.b), the co-existence of a registered name and an unregistered name designating a place in a Member State or in a third country where that name is identical to the registered name. ${ }^{97}$ The co-existence is feasible only if the following cumulative conditions are met:

\footnotetext{
${ }^{89}$ Art 8 (2) of Regulation 510/2006. However, this provision does not apply until 1 May 2009 so that operators have time to adjust to this obligation (art 20 para 2 thereof). "The use of such symbols or indications should be made obligatory in the case of Community designations, on the one hand, to make this category of products and the guarantees attached to them better known to consumers and, on the other, to permit easier identification of these products on the market so as to facilitate checks" (preamble thereof, at para 5).

90 Art 8 (3) of Regulation 510/2006.

${ }^{91}$ Directive 2000/13/EC of the European Parliament and of the Council of 20 March 2000 on the approximation of the laws of the Member States relating to the labelling, presentation and advertising of foodstuffs (2000) OJ L109/29 (as last amended by Directive 2003/89/EC of the European Parliament and of the Council of 10 November 2003 (2003) OJ L308/15; a consolidated version is downloadable from: http://eur-lex.europa.eu/LexUriServ/site/en/ consleg/2000/L/02000L0013-20040501-en.pdf).

92 See preamble of Regulation 510/2006, at para 5 and art 16 lit g thereof.

93 See COM(2005) 698 final/2, para 12 of the explanatory memorandum.

94 See $n 41$

95 See the symbols in Annex I part A of Regulation 2037/93 (see n 41) or at: http:// ec.europa.eu/comm/agriculture/foodqual/protec/logo_en.htm.

${ }^{96}$ Art 5a (2): "The Community symbol may appear only on products which comply with Regulation (EEC) No 2081/92 [now Regulation 510/2006]". It follows from that that the symbols may only be used on the products covered by the registration, ie they cannot be used on a product that only includes a PDO or PGI as an ingredient, or is a mixture of different PDOs or PGIs.

${ }_{97}$ Art 13 para 4 subpara 1 of Regulation 510/2006.
} 
- the identical unregistered name has been in legal use consistently and equitably for at least 25 years before 24 July 1993;98

- it is shown that the purpose of its use has not at any time been to profit from the reputation of the registered name and that the consumer has not been nor could be misled as to the true origin of the product;

- the problem resulting from the identical names was raised before registration of the name.

The registered name and the identical unregistered name concerned may co-exist for a period not exceeding a maximum of 15 years, after which the unregistered name shall cease to be used. Moreover, use of the unregistered geographical name concerned will be authorised only where the country of origin is clearly and visibly indicated on the label. ${ }^{99}$

\section{Protection attached to PDOs and PGIs}

Once a name is registered, whether it derives from a Member State or a third country, the most important question at that point is what rights are related to the registration. This question addresses the scope of protection under Regulation 510/2006. Registered names are protected in all Member States of the EU in accordance with art 13 of Regulation $510 / 2006$. As already mentioned (see supra IV.2), the protection afforded is the same for both designations of origin and geographical indications.

The subject of the protection is always the registered name. Art 8 (1) of Regulation 510/2006 stipulates that a name registered under this Regulation may be used by any operator marketing agricultural products or foodstuffs conforming to the corresponding specification. Only these persons have an exclusive right to use the PDO or PGI for their products. ${ }^{100}$ This is an intellectual property right, ${ }^{101}$ as are patents, trademarks and copyright. But, in contrast to these other intellectual property rights, not just a single person but all operators adhering to the product specification profit from the protection provided by Regulation 510/2006.

\footnotetext{
98 This is the date of the entry into force of Regulation 2081/92.

${ }_{99}$ Art 13 para 4 subparas 2 and 3 of Regulation 510/2006.

100 The enforcement of this exclusive right is organised and carried out by the Member States. Protection against breaches of PDO/PGI rights in international trade is provided by Council Regulation (EC) 1383/2003 of 22 July 2003 concerning customs action against goods suspected of infringing certain intellectual property rights and the measures to be taken against goods found to have infringed such rights (2003) OJ L196/7. For the possibility to register homonymous names - actually contravening the exclusive right - see art 3 (3) of Regulation 510/2006.

${ }_{101}$ This has been stated by the ECJ, for example in the "Parma case" (see n 53), para 64. Thereby, operators entitled to use the registered PDO/PGI for their products are enabled to prevent others from using it.
} 
Art 13 (1) (a) to (d) of Regulation 510/2006 sets out in detail those acts which constitute an infringement of the exclusive right to use the PDO/PGI:

- (a) any direct or indirect commercial use of a registered name in respect of products not covered by the registration insofar as those products are comparable to the products registered under that name or insofar as using the name exploits the reputation of the protected name;

- (b) any misuse, imitation or evocation, even if the true origin of the product is indicated or if the protected name is translated or accompanied by an expression such as "style", "type", "method", "as produced in", "imitation" or similar; ${ }^{102}$

- (c) any other false or misleading indication as to the provenance, origin, nature or essential qualities of the product, on the inner or outer packaging, advertising material or documents relating to the product concerned, and the packing of the product in a container liable to convey a false impression as to its origin;

- (d) any other practice liable to mislead the consumer as to the true origin of the product.

Where a registered name contains within it a generic name, the use of that generic name on the appropriate agricultural product or foodstuff is not considered to be contrary to points (a) or (b). ${ }^{103}$ Art 13 (2) of Regulation 510/2006 states furthermore that protected names may not

102 So, for example, the use of the name "Gambozola" for a blue cheese like "Gorgonzola" might lead to evocation and therefore could be forbidden. See case C-87/97 Consorzio per la tutela del formaggio Gorgonzola $v$ Käserei Champignon Hofmeister GmbH \& Co KG et al [1999] ECR I-1301, para 2 of the summary: "The concept of evocation covers a situation where the term used to designate a product incorporates part of a protected designation, so that when the consumer is confronted with the name of the product, the image triggered in his mind is that of the product whose designation is protected. It is possible for a protected designation to be evoked where there is no likelihood of confusion between the products concerned and even where no Community protection extends to the parts of that designation which are echoed in the term or terms at issue. Since the product at issue is a soft blue cheese which is not dissimilar in appearance to "Gorgonzola", it would seem reasonable to conclude that a protected name is indeed evoked where the term used to designate that product ends in the same two syllables and contains the same number of syllables, with the result that the phonetic and visual similarity between the two terms is obvious. Use of a name such as "Cambozola" may therefore be deemed, for the purposes of article 13 (1) (b) of Regulation No 2081/92 [now Regulation 510/2006], to evoke the protected designation of origin "Gorgonzola", irrespective of the fact that the packaging indicates the product's true origin". For a case comment, see Tibor Z. Gold, 'European Community: Trademarks - Re Designations of Origin' (4/1999) 21 EIPR 74. Another example is that non right-holders are not allowed to use an expression like "Parma style ham" or - as soon as Croatia becomes a member of the EU and after registration under Regulation 510/2006 - "Cheese as produced in Pag".

${ }^{103}$ Art 13 para 1 subpara 2 of Regulation 510/2006. 
become generic, whether or not operators defend their rights under art 13 (1) of Regulation 510/2006.

\section{Relationship with trademarks}

PDOs/PGIs and trademarks are different legal concepts. Trademarks personalise and identify products or services from a specific manufacturer, producer or service provider in order to differentiate such goods or services from all others. Behind the development of a trademark, human creativity is exclusively involved in creating an original and novel sign or expression which permits a certain product or service to be distinguished from similar products or services. A geographical indication is an expression that identifies geographically the origin of the product. It is linked to something more than mere human creativity, including topography, climate or other factors independent of human creativity. Therefore, the link between the product and its geographical origin cannot be broken and no delocalisation of production is possible. For example, "Ecuadorian bananas" as a geographical indication can only be used on bananas from Ecuador. In the case of the trademark "Dole Banana", this name could be used on bananas of whatever origin. Consequently, whereas trademarks put emphasis on the producer of a product, a geographical indication underlines the geographical origin of a good and the characteristics which derive therefrom. In addition, its use is not restricted to any one producer. Anyone satisfying the criteria may use the name. ${ }^{104}$

There are plenty of registered trademarks which consist of geographical names. Only some of them indicate the true origin of the product, such as, for example, "Prosciutto di Parma" for ham from the Italian town of Parma ${ }^{105}$ However, in most cases there is no link between the product and the area which gives its name. The fact that some registered trademarks consist of geographical names can lead in practice to conflicts between trademarks and geographical indications or designations of origin. ${ }^{106}$ Art 3 (4) and art 14 of Regulation 510/2006 deal with this problem by identifying three distinct situations and seek to strike the right balance between these two kinds of intellectual property rights:

- In principle, the registration of a conflicting trademark does not prevent the subsequent registration of the designation of origin or geographical indication. Only if, in the light of a trademark's reputation and renown and the length of time it has been used, regis-

\footnotetext{
${ }^{104}$ See Bernard O'Connor, 'The Legal Protection of Geographical Indications', (1/2004) Intellectual Property Quarterly, 35 , 44.

105 "Prosciutto di Parma" is protected within the EU as both a PGI and a Community trademark (trademark No 002249241; see http://oami.eu.int).

${ }^{106}$ An interesting example of such a conflict is the "Warsteiner case" (see n 28 and n 125).
} 
tration of the designation of origin or of the geographical indication was liable to mislead the consumer as to the true identity of the product, would the registration application be refused. ${ }^{107}$

- Where a designation of origin or a geographical indication is registered under Regulation 510/2006, the application for registration of a conflicting trademark must be refused if it is submitted after the date of submission of the application for registration of the designation of origin or a geographical indication to the Commission. Trademarks registered contrary to that rule must be invalidated. ${ }^{108}$

- The third situation provides for co-existence in cases where a trademark has been applied for, registered, or established by use in good faith within the territory of the EC before either the date of protection of the designation of origin or geographical indication in the country of origin, or before 1 January $1996 .{ }^{109}$

\section{Inspection structure}

Inspections are not carried out at Community level. Rather, the Member States or third countries are responsible for this task and have to organise their own inspection or control systems. ${ }^{110}$

\section{Selected ECJ cases dealing with PGI/PDO protection}

In the EU, it is sometimes very difficult to register a geographical indication or designation of origin because other Member States oppose it. They especially base their opposition on the claim that a certain geographical indication or designation of origin has become generic and as a consequence may not be registered pursuant to art 3 (1) of Regulation $510 / 2006$.

\footnotetext{
107 Art 3 (4) of Regulation 510/2006.

108 Art 14 (1) of Regulation 510/2006.

${ }^{109}$ Art 14 (2) of Regulation 510/2006. However, co-existence is to be denied if there are grounds for invalidity or revocation of the trademark under Council Directive 89/104/EEC of 21 December 1998 to approximate the laws of the Member States relating to trademarks (1989) OJ L40/1, or Council Regulation (EC) 40/94 of 20 December 1993 on the Community trademark (1994) OJ L11/1. See the "Gorgonzola case" (see n 102), para 43: "It is for the national court to decide whether, on the facts, the conditions laid down in article 14 (2) of Regulation No 2081/92 [now Regulation 510/2006] allow use of an earlier trade mark to continue notwithstanding the registration of the protected designation of origin "Gorgonzola", having regard in particular to the law in force at the time of registration of the trade mark, in order to determine whether such registration could have been made in good faith, on the basis that use of a name such as "Cambozola" does not, per se, constitute an attempt to deceive the consumer".

${ }^{110}$ For more on the mandatory inspection system, see $n 52$.
} 


\section{The "Feta case"}

In a recent case, the ECJ dismissed in a procedure under art 230 EC the applications of the Federal Republic of Germany and the Kingdom of Denmark for the annulment of Commission Regulation 1829/2002 ${ }^{111}$ with regard to the name "Feta" (the name of a Greek cheese). ${ }^{112}$

The "Feta case" has been a never ending dispute lasting more than 10 years. It started in 1994 when the Greek Government applied under the "simplified procedure" laid down in art 17 (1) of Regulation 2081/92 for registration of the word "Feta" as a designation of origin. ${ }^{113}$ Two years later, the European Commission registered this name accordingly by adopting Regulation $1107 / 96{ }^{114}$ This registration was then contested by Denmark, Germany and France pursuant to art 230 EC. By the judgment of 16 March 1999, the ECJ annulled Regulation 1107/96 insofar as it registered the name "Feta" as a PDO, because when registering the name "Feta", the European Commission had not taken any account whatsoever of the fact that that name had been used for a considerable time in certain Member States other than the Hellenic Republic. ${ }^{115}$ So, the Court found that the European Commission, in considering the question of whether "Feta" was a generic name, had not taken due account of all the factors set out in art 3 (1) of Regulation 2081/92 (now Regulation 510/2006). Following that judgment, the European Commission deleted the name "Feta" from the Register of PDOs/PGIs and from the Annex to Regulation 1107/96. ${ }^{116}$ Shortly after, the European Commission sent the Member States a questionnaire on the manufacture and consumption of cheeses known as "Feta" and on how well known that name was amongst consumers in each of the states. The information received in response to that questionnaire was presented to the Scientific Committee, which gave its opinion on 24 April 2001. In that opinion, the Committee concluded unanimously that the name "Feta" was not generic in nature. Subsequently, the European Commission adopted on 14 October 2002

\footnotetext{
111 Commission Regulation (EC) 1829/2002 of 14 October 2002 amending the Annex to Regulation (EC) No 1107/96 (2002) OJ L277/10. With regard to Commission Regulation $1107 / 96$, see n 39 .

112 See n 49.

${ }^{113}$ For more on the "simplified procedure", see n 39. The new Regulation 510/2006 does not contain any comparable provision to art 17 of the Regulation 2081/92.

114 See n 39. Under art 1 (1) of that Regulation, the name "Feta" in the Annex thereto in Part A, under the heading "cheeses" and the country "Greece", was registered as a protected designation of origin.

115 Joined cases C-289/96, C-293/96 \& C-299/96 Denmark and others $v$ Commission [1999] ECR I-1541 (“Feta I"), paras 101 et seq.

116 By adopting Commission Regulation (EC) 1070/1999 of 25 May 1999 amending the Annex to Regulation (EC) 1107/96 (1999) OJ L130/18.
} 
the Regulation 1829/2002. ${ }^{117}$ By that Regulation, the name "Feta" was once again registered as a PDO.

Subsequently, Germany and Denmark appealed once more against that Regulation, as mentioned above. They claimed that nothing had changed concerning their view that the name "Feta" had become generic. Moreover, according to them the name "Feta" as a non-geographical name did not fulfil the conditions required for registration set out in art 2 para 3 in connexion with para 2 (a) of Regulation 2081/92 (now art 2 para 2 of Regulation 510/2006). But this time the ECJ rejected the appeal, holding that on the one hand the European Commission was able to prove that the name "Feta" had not become generic, and on the other hand a series of factors, listed in the preamble of the contested Regulation, indicated that the characteristics of "Feta" were essentially or exclusively due to a particular geographical environment as required by art 2 para 3 and para 2 (a) of Regulation 2081/92. ${ }^{118}$ Para 36 of the contested Regulation reads as follows: "Extensive grazing and transhumance, central to the method of keeping the ewes and goats used to provide the raw material for making "Feta" cheese, are the result of an ancestral tradition allowing adaptation to climate changes and their impact on the available vegetation. This has led to the development of small native breeds of sheep and goats which are extremely tough and resistant, fitted for survival in an environment that offers little food in quantitative terms but, in terms of quality, is endowed with an extremely diversified flora, thus giving the finished product its own specific aroma and flavour. The interplay between the above natural factors and the specific human factors, in particular the traditional production method, which requires straining without pressure, has thus given "Feta" cheese its remarkable international reputation".

\section{The "Budvar case"}

Another interesting ECJ judgement concerns the protection of the name "Bud", which is used for both Czech and US beer. ${ }^{119}$ In this "Budvar case", some new terms - ie "simple and indirect indication of geographical source" - are used, which require a preliminary explanation. First, as described above (see IV.1), the scope of Regulation 510/2006 (at that time Regulation 2081/92) is limited to designations which have a link between the product or foodstuff characteristics and the geographical

117 See $\mathrm{n} 111$.

118 See $\mathrm{n} 112$.

119 Case C-216/01 Budéjovický Budvar, národní podnik v Rudolf Ammersin GmbH [2003] ECR I-13617. For a comment on that case, see Franz Urlesberger, 'Schutz einfacher Ursprungsbezeichnungen durch Mitgliedstaaten' (2004) Wirtschaftsrechtliche Blätter (wbl) 64 . 
origin. A name in respect of which there is no such direct link between a specific quality, reputation or other characteristic of the product and its specific geographical origin is known as a "simple" geographical indication and does not come within the scope of Regulation 510/2006, ie it cannot be registered. Secondly, an "indirect" indication of geographical source is a name which "is not in itself a geographical name but is at least capable of informing the consumer that the product bearing that indication comes from a particular place, region or country". ${ }^{120}$ The name "Bud" was, according to Advocate General Tizzano, an "indirect" geographical indication because it was "capable of evoking the Bohemian origin of the product by associating it with the city of Budweis". ${ }^{121}$

On 11 June 1976, Austria and Czechoslovakia concluded a bilateral agreement on the protection of indications of source, designations of origin and other designations referring to the source agricultural and industrial products. ${ }^{122}$ This agreement covered simple geographical indications, including both direct and indirect geographical indications (art 2 of the agreement). The Czechoslovak designations listed in the agreement, including "Bud", "Budejovické pivo" and "Budejovické pivo Budvar" - all of them names for beer products from Czech brewers in Budweis (Budéjovicky Budvar) - had to be reserved in Austria exclusively for Czechoslovak products (art 3 of the agreement). Each of the contracting states had to take all the necessary measures to ensure effective protection against unfair competition in the course of trade for the encompassed geographical indications (art 1 of the agreement).

The Austrian wholesale enterprise Ammersin marketed in Austria, inter alia, a beer called "American Bud", produced by the American brewery Anheuser-Busch. Ammersin bought the beer from the Austrian company Josef Sigl, the sole Austrian importer of that beer. In July 1999,

120 "Budvar case" (see n 119), para 54. See also Jeremy Reed, 'ECJ Protects Simple Geographical Indications for their Bud-dy' (1/2005) 27 EIPR 25: "Some food products might have a specific quality or reputation, but their quality or reputation is not due to the geographical environment of their origin or attributable to their geographical origin in any other way. Products bearing the name of their geographical origin for which there is no link between that geographical origin and any quality, characteristic or reputation which such products may (or may not) have are known as "simple" geographical indications. Protected geographical indications and protected designations have to use the actual names of the region, place or country; these might be termed "direct" geographical indications. Where the actual name of the place is not used (perhaps an abbreviation or a slang form of the name) but consumers still understand this name to indicate the geographical origin of the goods, this is known as an "indirect" geographical indication".

${ }^{121}$ Opinion of Advocate General Tizzano, case C-216/01 Budéjovický Budvar, národní podnik v Rudolf Ammersin GmbH [2003] ECR I-13617. It should be noted that "Budweis" is the German name for "Česke budejovicé". Even if Budweis is not the German translation of "Česke budejovicé", it was the historical name of the city at least until 1918.

${ }^{122}$ See BGBl 75/1981 as amended by BGBl III 123/1997, available at: http://www.ris.bka. gv.at. 
Budéjovický Budvar, a Czech brewery in the town of Budweis where it had produced beer since 1265, brought a claim against Ammersin in Austria by requesting the court that Ammersin be ordered to refrain from using on Austrian territory the name "Bud". In other words, Budéjovický Budvar wanted Ammersin to stop purchasing beer with the designation "American Bud" in Austria. Budéjovický Budvar relied, inter alia, on the bilateral agreement from 1976. ${ }^{123}$ The Austrian court finally referred questions to the ECJ concerning amongst others the compatibility of a bilateral agreement between a Member State and a non-member country, ${ }^{124}$ which gave absolute protection to "simple and indirect" indications of geographical origin, with art 28 EC and Regulation 2081/92 (now Regulation 510/2006).

The ECJ - while citing the "Warsteiner case"125 - came to the conclusion that since it was common ground that "simple and indirect" geographical indications were outside the scope of Regulation 2081/92 (now Regulation 510/2006), ${ }^{126}$ it followed that there was nothing in the

${ }^{123}$ The other claim relating to trademark rights will be disregarded here. For more on the trademark disputes between Budéjovický Budvar and Anheuser-Busch, see amongst others David F. Sheppard, 'South Africa, Trademarks - Trademark Budejovicky - Application for Registration - Likelihood of Confusion - Registration Refused' (6/2003) 25 EIPR 94; Antonio Corte-Real, 'The Budweiser Case in Portugal'(1/2002) 24 EIPR 43; Phil Sherrell, 'Trademarks - Budweiser' (5/2000) 22 EIPR 72; Monika Hirsch/Peter Poch, 'Austria: Trademarks - Protection of Geographical Indications' (7/2000) 22 EIPR 93; Andrew Inglis and Joel Barry, 'Budweiser: The Decision of Solomon' (8/1998) 20 EIPR 8.

${ }^{124}$ The Czech Republic was at that time not a Member State of the EU.

125 See $\mathrm{n}$ 28. In that case, Warsteiner Brauerei, a brewery in Warstein in Germany and owner of the trademark "Warsteiner" for Pilsner beer, was prevented by German trademark law from labelling its beer produced in Paderborn, a German town $40 \mathrm{~km}$ from Warstein, with the name "Warsteiner", because of the risk of misleading consumers. As it was a simple geographical indication, the name "Warsteiner" could not be registered in accordance with Regulation 2081/92 (now Regulation 510/2006). The ECJ held in a preliminary ruling procedure that a national (trademark law) provision which protected against the misleading use of simple geographical indications was not precluded by Regulation 2081/92 (now Regulation 510/2006). This ECJ judgement was based on the fact that Regulation 2081/92 (now Regulation 510/2006) only sought to harmonise EU-wide protection for products where there was a direct link between the specific quality, reputation or other characteristic of the product and its specific geographical origin. Regulation 2081/92 (now Regulation 510/2006) did not intend to regulate all geographical indications in the EU. The ECJ, however, did not expressly decide whether national protection could also be given to "simple and indirect" geographical indications. This question arose for the first time in the "Budvar case”. For a comment on the „Warsteiner case“, see Eva I. Obergfell, "Qualitätsneutrale” geographische Herkunftsangaben als Schutzdomäne des nationalen Rechts - Zur Entscheidung des EuGH vom 7.11.2000 - Rs. C-312/98 (Warsteiner)' (4/2001) Gewerblicher Rechtsschutz und Urheberrecht (GRUR) 313; and Karl H. Pilny, 'Germany: Trademarks - Geographical Indication' (8/2004)) 26 EIPR 131.

${ }^{126}$ See, for example, joined cases C-321/94, C-322/94, C-323/94 \& C-324/94 Criminal proceedings against Jacques Pistre et al [1997] ECR I-2343 ("Montagne"), paras 35, 36: "The description 'mountain' is quite general in character and transcends national frontiers, whereas, according to article 2 of Regulation No 2081/92 [now Regulation 510/2006], a di- 
Regulation which precluded absolute protection being given to simple and indirect geographical indications. ${ }^{127}$

Concerning compatibility with articles 28 and 30 EC, the ECJ held that the prohibition on marketing beer from countries other than the Czech Republic under the name of Bud in Austria, which follows from the bilateral agreement, was capable of affecting imports of that product under that name from other Member States and thus of constituting a barrier to intra-Community trade. Such a rule is therefore a measure with an effect equivalent to a quantitative restriction within the meaning of art $28 \mathrm{EC}$ and would be prohibited unless it could be justified under art 30 EC. ${ }^{128}$ A justification could be the protection of industrial and commercial property within the meaning of Art $30 \mathrm{EC}$, provided that the names in question had not become generic in the country of origin. ${ }^{129}$ Accordingly, articles 28 and $30 \mathrm{EC}$ "do not preclude the application of a provision of a bilateral agreement between a Member State and a non-member country, under which a simple and indirect indication of geographical origin from that non-member country is accorded protection in the Member State concerned, whether or not there is any risk of consumers being misled, and the import of a product lawfully marketed in another Member State may be prevented, provided that the protected name has not, either at the date of the entry into force of that agreement or subsequently, become generic in the State of origin". ${ }^{130}$ However, if the bilateral agreement ac-

rect link must exist between the quality or characteristics of the product and its specific geographical origin. ... [A]n indication of provenance is intended to inform the consumer that a product bearing such an indication comes from a particular place, region or country".

127 "Budvar case" (see n 119), paras 71 to 78: Regulation 2081/92 (now Regulation $510 / 2006$ ) "does not preclude the application of a provision of a bilateral agreement between a Member State and a non-member country under which a simple and indirect indication of geographical origin from that non-member country is accorded protection in the importing Member State, whether or not there is any risk of consumers being misled, and the import of a product lawfully marketed in another Member State may be prevented".

${ }^{128}$ Ibid, paras 96 and 98 .

${ }^{129}$ Ibid, para 99. See also the "Emmenthal case" (see n 68), para 35, where the ECJ held that art $28 \mathrm{EC}$ "precludes a Member State from applying to products imported from another Member State, where they are lawfully produced and marketed, a national rule prohibiting the marketing of a cheese without rind under the designation Emmenthal in that Member State". In other words, a national rule protecting a generic designation like "Emmenthal" constitutes a measure with an effect equivalent to a quantitative restriction contrary to art $28 \mathrm{EC}$ which cannot be justified by overriding requirements relating, inter alia, to fair trading and consumer protection (paras 27 to 31 ).

130 Ibid, para 102. With regard to the national protection of non-generic names, see the "Gorgonzola case" (see n 102), para 20: "Articles 28 and 30 EC do not preclude the application of rules laid down by a bilateral convention between Member States on the protection of indications of provenance and designations of origin, provided that the protected names have not become generic in the country of origin ... A fortiori, they do not preclude Member States from taking the measures necessary for the protection of names registered in accordance with Regulation No 2081/92 [now Regulation 510/2006] and which, as such, pursuant to article 3 of that regulation [now Regulation 510/2006], are not generic". 
corded protection in the importing Member State not only to "simple and indirect" indications but also to names which do not directly or indirectly refer to the geographical source of the product, the agreement insofar would be incompatible with art $28 \mathrm{EC}$. $^{131}$ This conclusion is not surprising, because a name which does not directly or indirectly refer to its geographical origin cannot be regarded as a geographical indication in the sense of Regulation 510/2006 - it is a trademark. ${ }^{132}$

In practical terms, this ECJ judgment meant that Austria was "allowed" to apply the bilateral agreement insofar as it was compatible with EC law. In the meantime, the legal ground for protection of Budweis beer has changed, as the Czech Republic became a member of the EU. Since 1 May 2004, "Budẽjovické pivo”, "Budějovický měst'anský var" and "Českobudějovické pivo" are registered and therefore protected geographical indications for beer within the EU according to the accession treaty. ${ }^{133}$ As soon as a name is protected at Community level by registration under Regulation 510/2006, Member States must terminate national protection - as for example by way of the bilateral agreement in question - of that name. ${ }^{134}$ Austrian courts now have to clarify whether the unregistered name "Bud" directly or indirectly refers - in relation to beer - to the Czech town of Budweis. ${ }^{135}$ Only when they decide in the affirmative may the bilateral agreement be applied without infringing EC law.

Taking into account the ECJ cases up to now, the situation as to the relation of Regulation 510/2006 to national law protecting geographical indications and designations of origin is the following:

\footnotetext{
${ }^{131}$ Ibid, para 111. The ECJ also had to deal with the question whether art 307 EC prevented Austria from enforcing the bilateral agreement if it was incompatible with art $28 \mathrm{EC}$ because of the before-mentioned reason. According to the ECJ, the right answer depended on whether the bilateral agreement bound Austria at the date of its accession to the EU as a matter of international law or not. For more on this, see ibid, paras 112 et seq. See further Jeremy Reed (see n 120), p 28.

${ }^{132}$ See Jeremy Reed (see n 120), p 28.

133 See Annex II.6 of the accession treaty, (2003) OJ L236/359 (para 18): "The names "Budějovické pivo", "Českobudějovické pivo" and "Budějovický měst'anský var" shall be registered as protected geographical indications (PGI) and listed in the Annex in accordance with specifications submitted to the Commission. This is without prejudice to any beer trademark or other rights existing in the European Union on the date of accession".

${ }^{134}$ See joined cases C-129/97 \& C-130/97 Criminal proceedings against Yvon Chiciak et al [1998] ECR I-3315, paras 28, 33: "[T]he 1992 regulation must be interpreted as meaning that, since its entry into force, a Member State may not, by adopting provisions of national law, alter a designation of origin for which it has requested registration in accordance with article 17 and protect that designation at national level"; the "Gorgonzola case" (see n 102), para 18 (protection afforded by a Member State to a registered designation of origin must stop even when the national protection is wider in scope than that available under Community law); and the "Budvar case" (see n 119), para 74.

135 See the decision of the Austrian Supreme Court (OGH) of 29 November 2005, $4 \mathrm{Ob}$ 127/05p, available at: http://www.ris.bka.gv.at.
} 
- National protection of generic names or names which do not directly or indirectly refer to the geographical source of the product infringes art $28 \mathrm{EC}$.

- The protection of simple and indirect geographical indications at national level is compatible with EC law.

- Moreover, Regulation 510/2006 does not preclude the application of domestic rules protecting designations containing specific geographical references, which, if there were links between the characteristics of the products which those designations evoke and the geographical area to which they refer, could be registered under that regulation. ${ }^{136}$ This also applies in the absence of an application for registration.

- However, in the absence of an application for registration of a name, the national authorities cannot legitimately rely on the provisions of Regulation 510/2006 in order to protect that name. ${ }^{137}$

- But if a Member State forwards an application for registration to the European Commission, it may, on a transitional basis only, grant on the national level a protection in the sense of Regulation $510 / 2006$ to the name forwarded until a decision on registration under this Regulation is taken (art 5 para 5 of Regulation 510/2006).

\section{The forthcoming "Czech wafers and cheese case"?}

In October 2004, Czech producers filed applications for the registration of the designations "Karlovarske oplatky" (wafers from the spa town of Karlove Vary) and "Pravé olomoucké tvar žky" (cheese from the Morava region). ${ }^{138}$ On being confronted with these applications, Austrian and German members of the European Parliament (MEP) reacted quite emotionally by asking for the historic perspective of the issue to be considered. A German MEP (Bernd Posselt) feared for the production of Bavarian wafers under the name "Karlsbader Oblaten", whereas an Austrian colleague (Agnes Schierhuber) worried about the "Olmutzer Quargel", a type of Austrian cheese. According to the German MEP, the original procedure was brought to the Bavarian region after Sudeten Germans living in the area close to the spa town of Karlove Vary had been forced to

\footnotetext{
136 "Warsteiner case" (see n 28), para 47.

137 See case C-6/02 Commission of the European Communities $v$ French Republic [2003] ECR I-2389, para 10.

${ }^{138}$ See the 'List of applications for registration of Protected Designations of Origin (PDO) and Protected Geographical Indications (PGI) under Regulation (EEC) 2081/92 [now Regulation 510/2006], for which no First Publication has been made' <http://ec.europa.eu/ comm/agriculture/foodqual/protec/ applications/list_en.pdf>.
} 
leave the Czech Republic, under the Beneš decrees adopted in 1945. The Czech producers, by contrast, stressed that, in the case of the wafers, the products were specific due to the spa water in Karlove Vary, while the Olmouc cheese makers highlighted the geographical characteristics of production. In addition, a Czech MEP (Jan Brezina) argued, that "if we want to secure a peaceful life together between the Czechs, Austrians and Germans, we should not once again bring back sensitive memories of the historic events of over 50 years ago". ${ }^{139}$

This row is a striking example of the difficulties that might arise during the registration process of certain geographical indications. The applications of the Czech producers are currently being examined by the European Commission. Whatever decision the Commission takes, a lawsuit at the ECJ seems inevitable, taking into account the rigid statements of the said MEPs.

\section{Protection of geographical indications within the WTO}

In 1994, the WTO Agreement on Trade-Related Aspects of Intellectual Property Rights (TRIPS) ${ }^{140}$ established binding international obligations for the protection of geographical indications. ${ }^{141}$ The TRIPS Agreement does not specify how geographical indications should be protected in individual countries, nor does it require the creation of a distinct regime for their protection: in other words, the means of protection are not spelled out.

The TRIPS Agreement provides for two levels of protection: all products are covered by art 22, which defines a standard level of protection: geographical indications have to be protected in order to avoid misleading the public and to prevent unfair competition. Art 23 provides an additional, higher level of protection for geographical indications for wines and spirits: subject to a number of exceptions, they have to be protected even if misuse would not cause the public to be misled. That is to say, it is not necessary to show that the public might be misled or that the use constitutes an act of unfair competition. Thus, art 23 gives a stronger protection for wines and spirits than that provided for in art 22 for all products.

Geographical indications are defined in art 22 (1) of the TRIPS Agreement as "indications which identify a good as originating in the territory of a Member, or a region or locally in that territory, where a given quality, reputation or other characteristic of the good is essential-

\footnotetext{
${ }^{139}$ See 'Czech wafers highlight post-war row with Germany' (23 November 2005) <http:// euobserver.com>.

140 See $n 8$.

${ }^{141}$ For an overview, see O'Connor (see n 104), p 52.
} 
ly attributable to its geographical origin". Only goods originating in the specified territory may bear the geographical indication, which, it is assumed, gives them a competitive advantage. Examples of geographical indications within the WTO are: Tequila (Mexico), Ceylon tea (Sri Lanka), Antigua coffee (Guatemala), Gobi camel wool (Mongolia), Café do Cerrado (Brazil), Catamarca oil (Argentina), Maipo Valley wine (Chile), Hom Mali rice (Thailand), Basmati rice (India).

According to art 22 (2), WTO members "shall provide the legal means for interested parties to prevent the use of any means in the designation or presentation of a good that indicates or suggests that the good in question originates in a geographical area other than the true place of origin in a manner which misleads the public as to the geographical origin of the good". The same applies to "any use [of geographical indications] which constitutes an act of unfair competition". Geographical indications relating to products other than wines and spirits are therefore regarded as a "negative" right or a right to prevent, rather than a "positive" right, such as a right to authorise use. ${ }^{142}$

Art 23 of the TRIPS Agreement affords additional protection for geographical indications of wines and spirits. "Each WTO Member shall provide the legal means for interested parties to prevent use of a Geographical Indication identifying wines for wines not originating in the place indicated by the Geographical Indication in question or identifying spirits for spirits not originating in the place indicated by the Geographical Indication in question, even where the true origin of the goods is indicated or the Geographical Indication is used in translation or accompanied by expressions such as 'kind', 'type', 'style', 'imitation' or the like". The practical effect of this provision is to permit interested parties to prevent, without having to prove that the public is misled or that there is an act of unfair competition,

- the use of the geographical indication by others, generally, for products not originating in the place indicated by the geographical indication in question (eg unqualified use of Bordeaux wine by Indian producers in India);

- the use of the geographical indication even in conjunction with an additional indication in which the true place of origin of the products is indicated (eg, Bordeaux wine of USA);

- the use of the geographical indication even if the geographical indication is used in translation (eg Burgundy, Champaña, Coñac or Valle de los Cactus [instead of Napa Valley]); and

${ }^{142}$ See Alberto F.Ribeiro de Almeida, 'The TRIPS Agreement, the Bilateral Agreements Concerning Geographical Indications and the Philosophy of the WTO' (4/2005) 27 EIPR 150, 151. 
- the use of the geographical indication if it is accompanied by an expression such as "kind", "type", "style", "imitation" or the like (eg Scotch-type Whisky).

The following example should clarify the difference between the protection under articles 22 and 23: the use of a geographical indication such as Napa Valley wine for a wine produced in Austria is prohibited, while at the same time it is allowed to produce Antigua-style coffee in Austria.

Art 22 (2) and art 23 (2) of the TRIPS Agreement deal with the relationship between trademarks and geographical indications. Art 24 of the TRIPS Agreement includes some exceptions to the protection requirements.

\section{WTO "case law" related to the protection of geographical indications}

The TRIPS Agreement is subject to the binding WTO dispute settlement system. Consequently, all disputes concerning the application or interpretation of the TRIPS Agreement must be resolved through recourse to dispute settlement in accordance with the rules and procedures of the WTO Dispute Settlement Understanding (DSU). ${ }^{143}$ So far, Section 3 of the TRIPS Agreement on geographical indications has been only once subject to a WTO dispute. This particular case concerned the former EC framework for the protection of geographical indications under Regulation $2081 / 92$.

In 1999, the USA requested consultations with the EU in respect of Regulation 2081/92. ${ }^{144}$ But first some preliminary remarks on the US protection system are needed to understand the US position in that dispute. The United States has no sui generis legislation dealing with the protection of geographical indications. Rather, protection derives in the USA from a collection of unrelated laws and regulations, in which the certification mark is the principal method to protect geographical indications from becoming generic under US law. Thus, implementation of Section 3 of the TRIPS Agreement and legal protection of geographical indications are obtained via the registration of names as certification trademarks. With this background, it is not surprising that the USA was a declared opponent to the much more restrictive protection system provided for by

\footnotetext{
143 'Understanding on rules and procedures governing the settlement of disputes' <http:// www. wto.org/english/docs_e/legal_e/28-dsu.doc>.

${ }^{144}$ See 'European Communities - Protection of Trademarks and Geographical Indications for Agricultural Products and Foodstuffs - Request for Consultations by the United States' (WT/DS174/1, 7 June 1999) <http://docsonline.wto.org/gen_search. asp?searchmode $=$ simple $>$.
} 
Regulation 2081/92. ${ }^{145}$ Specifically, the USA contended, inter alia, that Regulation 2081/92 did not provide "national treatment" pursuant to art 3 (1) of the TRIPS Agreement ${ }^{146}$ and art III of the GATT $1994^{147} 148$ with respect to the protection of geographical indications. Australia followed these allegations by filing a separate WTO complaint in 2003. ${ }^{149}$ According to both WTO members, the Regulation effectively limited the use of geographical indications to products originating in the EU, thereby placing imports at a competitive disadvantage.

As the consultations did not result in a mutually agreed solution, both complaining parties went on with the next step in the WTO dispute settlement system by requesting the establishment of a WTO Panel to examine the alleged infringement of WTO Law.

On 15 March 2005, the Panel ruled on the case, rejecting the majority of claims made by the USA and Australia. ${ }^{150}$ While the Panel found several aspects of Regulation 2081/92 to be inconsistent with the TRIPS Agreement and GATT 1994, it did not condemn the registration system as a whole but simply recommended that it should be amended to correct the violations. More precisely, the Panel found among other things that the provisions of Regulation 2081/92 relating to the availability of geographical indications protection for names of third countries ${ }^{151}$ and those relat-

${ }^{145}$ The US complaint was also driven by the fear that the Czech brewery Budejovicky Budvar would use Regulation 2081/92 to claim protection for the Budweiser trademark once the Czech Republic joined the EU and thereby prevent the American brewer AnheuserBusch from using this name in the EU (see Economist, 10 July 1999, p 71).

${ }^{146}$ Agreement on Trade-Related Aspects of Intellectual Property Rights, available at: http:// www.wto.org/english/docs_e/legal_e/legal_e.htm.

147 General Agreement on Trade and Tariffs, available at: http://www.wto.org/english/ docs_e/ legal_e/legal_e.htm.

148 The national treatment obligation under the TRIPS Agreement requires that each WTO member accords to the nationals of other WTO members treatment no less favourable than it accords to its own nationals. The national treatment obligation under GATT 1994 requires equal treatment of products produced in another member's territory with domestic products.

149 See 'European Communities - Protection of Trademarks and Geographical Indications for Agricultural Products and Foodstuffs - Request for Consultations by Australia' (WT/DS290/ 1 , 23 April 2003) <http://docsonline.wto.org/gen_search.asp?searchmode=simple>.

150 See 'European Communities - Protection of Trademarks and Geographical Indications for Agricultural Products and Foodstuffs' (WT/DS174/R and WT/DS290/R, Report of the Panel, adopted by the WTO Dispute Settlement Body on 20 April 2005) <http://www.wto. org/english/tratop_e/dispu_e/find_dispu_cases_e.htm>.

${ }^{151}$ Art 12 of Regulation 2081/92 afforded protection for geographical indications of products originating in territory outside the EU, but only under the conditions of reciprocity and equivalence. In the Panel's view, meeting these criteria was a burden and constituted "less favourable treatment" of non-EU products in violation of both the TRIPS Agreement and GATT. 
ing to the procedures for obtaining geographical indications protection ${ }^{152}$ discriminate against products originating outside the EU. As such, they violate the national treatment obligation of both the TRIPS Agreement and GATT 1994. Taken together, the EU claimed victory because it would be allowed to maintain a system that limits within the EU the use of EU-origin indications to products that actually come from the named location. ${ }^{153}$ In any case, the EU had to implement the recommendations and rulings of the Panel, which were adopted by the Dispute Settlement Body (DSB), by 3 April 2006. ${ }^{154}$ To meet the deadline, the European Commission proposed on 23 December 2005 to the Council of the EU a revised regulation on geographical indications. ${ }^{155}$ This proposal resulted in the abovedescribed Regulation 510/2006, which applies from 31 March 2006. Regulation 510/2006 replaces Regulation 2081/92 as a whole and brings the EU framework into conformity in the two areas that were criticised: firstly, regarding the availability claim, by formally revoking the existing provisions on reciprocity and equivalence, and secondly, as to the procedure claim, by allowing third country operators to submit applications and objections directly rather than through their governments.

\section{Negotiations on the advancement of the WTO system relating to the protection of geographical indications}

When concluding the TRIPS Agreement, it was agreed that negotiations should be undertaken on the establishment of a multilateral system of notification and registration of geographical indications for wines eligible for protection in those WTO members participating in the system. Pursuant to art 23 (4) of the TRIPS Agreement, the stated objective of establishing such a multilateral register is to facilitate the protection of geographical indications for wines. Furthermore, art 24 states that "Members agree to enter into negotiations aimed at increasing the protection of individual geographical indications".

Based on both these provisions and the Doha mandate, ${ }^{156}$ WTO members are currently negotiating on the establishment of a notification and registration system, as well as an extension of the protection of

\footnotetext{
${ }^{152}$ So, for example, operators of third countries had to send an application for registration to the authorities in the country in which the geographical area was located rather than sending it directly to the European Commission (see art 12a para 1 of Regulation 2081/92). The same applied to statements of objections (art 12d para 1 thereof).

153 See "WTO Panel upholds EU system of protection of geographical indications", IP/05/298, 15 March 2005.

${ }^{154}$ See WT/DS174/24 and WT/DS290/22, 13 June 2005; and Status Report by the European Communities, WT/DS174/25/Add.3 and WT/DS290/23/Add.3, 11 April 2006.

155 COM(2005) 698 final/2, 5 January 2006.

${ }^{156}$ See para 18 of the Doha Ministerial Declaration (WT/MIN(05)/DEC, 22 December 2005) <http://www.wto.org/english/thewto_e/minist_e/min05_e/final_text_e.htm>.
} 
geographical indications provided for in art 23 of the TRIPS Agreement to products other than wines and spirits. But because of two completely different approaches concerning the enhancement of the current geographical indications protection within the WTO - an extensive one supported especially by the EU, and a restrictive one favoured by the USA ${ }^{157}$ - the negotiations are very difficult and have not yet led to a result. ${ }^{158}$

\section{Closing remarks to the starting question}

Returning to the introductory question on the protection of Dalmatinski pršut after Croatia's accession to the EU, the answer is the following: in the pre-accession period, protection will be provided by national (ie Croatian) law, by the TRIPS Agreement, and possibly by Regulation 510/2006. At the international level, art 22 of the TRIPS Agreement prevents Slovenian ham producers from using the designation Dalmatinski pršut for Slovenian ham if there is a risk of the public being misled or if it constitutes an act of unfair competition. But, on the other hand, the TRIPS agreement does not prevent the use of designations such as "Ham as produced in Dalmatia" or "Dalmatia-type ham". In the latter case, Croatia could only forbid by Croatian law the marketing of these products on Croatian territory. To obtain protection within the EU, Croatian producers would have to send an application for registration together with a specification to the European Commission - either directly or via the competent Croatian authority. One requirement for the registration would be that the designation Dalmatinski pršut was protected in Croatia by Croatian law.

After becoming a Member State of the EU, Croatia has to cease at national level the protection of its geographical indications and designations of origin registered under Regulation 510/2006, unless the European Commission adopts a transitional arrangement or if a transitional period is provided by the accession treaty. Once Dalmatinski pršut is registered as a PDO or PGI, any operator marketing agricultural products or foodstuffs conforming to the corresponding specification may use this name.

${ }_{157}$ A list of all proposals submitted by WTO members so far is included in the website: http://www.wto.org/english/tratop_e/trips_e/gil_docs_e.htm.

${ }^{158}$ One (main) reason for the difficulties is the very differing means for the protection of geographical indications at national level among the WTO members. For an overview, see in WTO document 'Overview of existing international notification and registration systems for geographical indications relating to products other than wines and spirits' (IP/C/W/85/Add.1, 2 July 1999) <http://docsonline.wto.org/ DDFDocuments/t/IP/C/W85A1.DOC>. For further information, see the information sheet provided by the Organization for an International Geographical Indications Network (oriGIn), 'WTO negotiations in relation to geographical indications' <http://origin.technomind.be/fileadmin/origin/PDFs/English/GI_Info/Legal_ Info/ WTO_negotiations_on_GIs.pdf>; and the WTO official background briefing note, 'Background and the current situation' <http://www.wto.org/english/tratop_e/trips_e/gi_background_ e.htm>. See also W. Van Caenegem, 'Registered GIs: Intellectual Property, Agricultural Policy and International Trade' (4/2004) 26 EIPR 170; and O’Connor (see n 104), p 54 et seq. 